\title{
Responses to the Criticism About "Drug Demand Function for Iranian Urban Households Based on Households' Budget”
}

\author{
Ramin Ravangard ${ }^{1}$; Abdosaleh Jafari ${ }^{1,}$; Soraya Nouraei Motlagh ${ }^{2}$ \\ ${ }^{1}$ Health Human Resource Research Center, School of Management and Information Sciences, Shiraz University of Medical Sciences, Shiraz, IR Iran \\ ${ }^{2}$ Department of Health Economics, School of Health Management and Information Sciences, Tehran University of Medical Sciences, Tehran, IR Iran \\ ${ }^{*}$ Corresponding author: Abdosaleh Jafari, Health Human Resource Research Center, School of Management and Information Sciences, Shiraz University of Medical Sciences, Shiraz, \\ IR Iran. Tel: +98-7112340774, Fax: +98-7112340039, E-mail: jafari_ab@sums.ac.ir
}

Received: December 25, 2014; Revised: January 18, 2015; Accepted: February 1, 2015

Keywords: Consumption; Households; Demand

\section{Dear Editor,}

The authors, in addition to thanking the honorable critic for expressing his opinions, have provided the following responses to his criticisms:

\section{Response to Criticism 1:}

In the health sector, the demand for health care is measured by both the quantity of services used (such as inpatient days, outpatient visits, or prescriptions) and the total cost of services. The latter allows for the combination of services measured in different quantity units. Both of these methods, i.e. the use of the quantity and the total cost, can be used to estimate the elasticity of the demand (1). In many studies, the total cost has been used to estimate the demand function, some of which have been provided in the references (2-7).

\section{Response to Criticism 2:}

As explained above, the total cost can be used for estimating demand. Also, the honorable critic has mentioned that "Increasing in drug prices would decrease the demand for drugs". The health care market faces a phenomenon called "market failure", which has effects on some issues such as demand elasticity. It should be noted that moral hazard, adverse selection, supplier induced demand, and so on have significant effects on the demand elasticity. In some studies, the researchers have used sophisticated statistical techniques to identify the degree of market failures (e.g. adverse selection) and decompose their total effects on demand $(1,8,9)$. However, in the present article, the authors have not investigated the effects of moral hazard, adverse selection, and the like on demand because of some problems, including the lack of access to the required data, mentioned in the 'Study Limitations' section.

\section{Response to Criticism 3:}

The honorable critic has mentioned that "A surprising econometrics method was used to estimate the effects of explanatory variables on drug expenditures in the article. This method had been disaffirmed all econometrics methods established in the century". The model used in this study is a multivariate model and the variables entered into this model are somewhat similar to those in other Iranian studies $(2,3)$. In addition, in this study the logarithmic form has been used in order to estimate the elasticity. Goldman and colleagues (2004) in their study have also used a generalized linear model with a logarithmic link function to estimate the drug spending (10). Besides, the researchers in the different studies have used a variety of econometric models for estimating demand in the health sector. For example, in some studies, like the present one, the researchers have used ordinary least squares method (11-13). While in other studies, the researchers have used the two-part model. That is, they first used probit model and then log linear model (14). Still, in some other studies, the researchers have used the "Hurdle" model $(15,16)$. In the Iranian studies also the researchers have used some models, including ordered probit, multinomial logit, and Zero inflated regression models (17-19). The process of selecting an econometric model to estimate the demand for health care has been described by Mariko (2003) (20).

Moreover, the honorable critic has claimed that in the current article the authors have used the unit root test to determine the autocorrelation!!! However, the authors have mentioned in the 'Abstract,' 'Methods,' and 'Results' sections that the unit root test has been used for determining whether the variables have been stationary. For example, in the 'Method' section, they have mentioned that:

"In this study, augmented Dickey-Fuller (ADF) test was

Copyright (C) 2015, Health Promotion Research Center. This is an open-access article distributed under the terms of the Creative Commons Attribution-NonCommercial 4.0 International License (http://creativecommons.org/licenses/by-nc/4.0/) which permits copy and redistribute the material just in noncommercial usages, provided the original work is properly cited. 
used to show that whether variables were stationary or not. This test is a test for a unit root in a time-series sample and is a version of the Dickey-Fuller test for a larger and more complicated set of time series models".

On the other hand, in order to determine the autocorrelation, the authors of this article have used the DurbinWatson Statistic. As they have mentioned in the 'Results' section that:

"The Durbin-Watson statistic (DW = 2.04) showed that estimated equation had not any serial correlation."

Furthermore, the critic has claimed that the researchers in the current article "decided to eliminate some of the variables had unit root from the base model". However, this was not the case in this article. The following sentence in the article can explain this issue more:

"Table 2 shows the results of the estimating equation after removing autocorrelation."

Finally, it should be noted that the authors have tried to refer to a lot of Iranian and non-Iranian articles indexed in the valid cites in order to clarify the issues raised by the critic.

\section{References}

1. Ringel JS, Hosek SD, Vollaard BA, Mahnovski S. The Elasticity of Demand for Health Care. A review of the literature and its application to the military health system.: DTIC Document; 2002.

2. EbadifardAzar F, Rezapoor A, Rahbar A, Hosseini Shokouh SM. Estimation of the Function of Medicine Demand in Islamic Republic of Iran.J Mil Med. 2013;15(2):163-8.

3. Rahbar A, Barouni M, Bahrami MA, Saber Mahani A. Estimation of Drug Demand Function in Iranian Urban Population through Household Budget, 1990-2011. Tolooebehdasht. 2013;12(3):44-58.

4. Eichner MJ. The demand for medical care: What people pay does matter. American Econ Review. 1998:117-21.

5. Klein R. Joseph P. Newhouse and the Insurance Experiment
Group, Free For All? Lessons from the Rand Health Insurance Experiment Cambridge, Mass: Harvard University Press, 1993. J Pub Policy. 2008;14(01):91.

6. Phelps CE, Newhouse JP. Coinsurance, The Price of Time, and the Demand for Medical Services. Rev Econ Stat. 1974;56(3):334.

7. Rosett RN, Huang LF. The Effect of Health Insurance on the Demand for Medical Care. J Polit Econ. 1973;81(2):281.

8. Zweifel P, Manning WG. Chapter 8 Moral hazard and consumer incentives in health care. In: Culyer A, Newhouse J editors. Handbook of Health Economics.. New York: Elsevier; 2000. pp. 409-59.

9. Weiner JP.The Demand for Physician Services in a Changing Health Care System: A Synthesis. Med Care Res Review. 1993;50(4):411-49.

10. Goldman DP. Pharmacy Benefits and the Use of Drugs by the Chronically Ill. Jama. 2004;291(19):2344.

11. Hurd MD, McGarry K. Medical insurance and the use of health care services by the elderly.J Health Econ. 1997;16(2):129-54.

12. Buntin MB, Zaslavsky AM. Too much ado about two-part models and transformation? Comparing methods of modeling Medicare expenditures.J Health Econ. 2004;23(3):525-42.

13. Mullahy J. Much ado about two: reconsidering retransformation and the two-part model in health econometrics. J Health Econ. 1998;17(3):247-81.

14. Duan N, Manning WG, Morris CN, Newhouse JP. A Comparison of Alternative Models for the Demand for Medical Care. J. Bus Econ Stat. 1983;1(2):115-26.

15. Pohlmeier W, Ulrich V. An Econometric Model of the Two-Part Decisionmaking Process in the Demand for Health Care. J Hum Resour. 1995;30(2):339.

16. Cameron A, Colin Trivedi PK. Regression analysis of count data. 2ed edCambridge: Cambridge university press; 1998.

17. Jafari A, Ravangard R, Kavosi Z, Sajjadnia Z. Estimation of the demand for health for urban households using Grossman's model in Shiraz, Iran. Prog Health Sci. 2014;4(1):31-40.

18. Kermani MS, Ghaderi H, Yousefi A. Demand for medical care in the urban areas of Iran: an empirical investigation. Health Econ. 2008;17(7):849-62.

19. Doroh VR, Hatam N, Jafari A, Kafashi S, Kavosi Z. Determinants of Outpatient Services Utilization in Shiraz, 2012.J Community Med Health Educ. 2013;3(216):2161-711.1000216.

20. Mariko M. Quality of care and the demand for health services in Bamako, Mali: the specific roles of structural, process, and outcome components. Soc Sci Med. 2003;56(6):1183-96. 